\title{
Nitrogen utilization in ice algal communities of Barrow Strait, Northwest Territories, Canada
}

\author{
W. G. Harrison ${ }^{1}$, G. F. Cota ${ }^{2}$, R. E. H. Smith ${ }^{3}$ \\ ${ }^{1}$ Department of Fisheries \& Oceans, Biological Oceanography Division, Bedford Institute of Oceanography, Box 1006, \\ Dartmouth, Nova Scotia, Canada B2 Y 4A2 \\ ${ }^{2}$ Graduate Program in Ecology, University of Tennessee, Knoxville, Tennessee 37996-1610, USA \\ ${ }^{3}$ Biology Department, University of Waterloo, Waterloo, Ontario, Canada N2L 3G1
}

\begin{abstract}
Studies of the utilization of inorganic nitrogen $\left(\mathrm{NO}_{3}{ }^{-}, \mathrm{NH}_{4}{ }^{+}\right)$by sea-ice algal communities were conducted during 2 field seasons in Barrow Strait, Northwest Territories (NWT), Canada. Results showed a significant temporal shift from $\mathrm{NO}_{3}{ }^{-}$-dominated metabolism during the early stages of algal biomass accumulation under the ice to $\mathrm{NH}_{4}{ }^{+}$-dominated metabolism later on when biomass was in decline. Volume-based uptake rates of both nitrogen compounds were 2 to 3 orders of magnitude higher

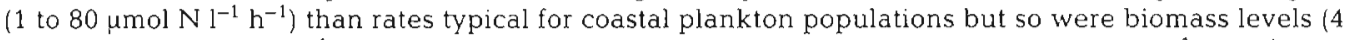
to $18 \mathrm{mg}$ chlorophyll a $\left.\mathrm{l}^{-1}\right)$ and interstitial nitrogen concentrations $\left(\mathrm{NO}_{3}^{-}: 4\right.$ to $123 \mu \mathrm{mol} \mathrm{N} \mathrm{l}{ }^{-1}, \mathrm{NH}_{4}^{+}: 4$ to

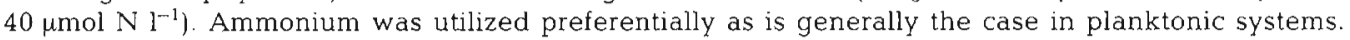
Despite high concentrations, however, $\mathrm{NH}_{4}{ }^{+}$apparently had little inhibitory effect on the activity of the $\mathrm{NO}_{3}{ }^{-}$assimilatory enzyme, nitrate reductase (NR), at least during the early stages of ice-algal growth. Complementary physiological experiments carried out during this same period showed (1) concentration-dependent nitrogen uptake kinetics $\left(\mathrm{K}_{\mathrm{s}}\right)$ for these communities were similar to values seen in coastal plankton, (2) no apparent light-dependence of $\mathrm{NO}_{3}{ }^{-}$or $\mathrm{NH}_{4}{ }^{+}$uptake was evident in short-term experiments, (3) organic nitrogen (urea, amino acids) may represent a significant portion of the sea-ice communities nitrogen nutrition, (4) an important component of the metabolism of $\mathrm{NH}_{4}{ }^{+}$and amino acids may be mediated by prokaryotic microorganisms. Our results, along with several other indirect lines of evidence, support the contention that these sea-ice communities are not nitrogen-limited.
\end{abstract}

\section{INTRODUCTION}

The existence of complex communities of primary producers, grazers and bacteria residing at the seawater-ice interface in polar seas has been known for many years (Horner 1985a). There has been much speculation on the ecological role of these communities (Horner 1985b, Conover et al. 1990) but only in recent years has a concerted effort been made to study their component parts, their trophic interactions and the physiological characteristics which enable them to survive and proliferate in this unique but hostile environment. Most work has focussed on the photoautotrophs (sea-ice algae) and has largely concentrated on their photosynthetic, biochemical and growth response to light (e.g. Cota 1985, Palmisano et al. 1985, Smith et al. 1987, 1988, 1989b, Michel et al. 1988) although the effects of other physical and chemical properties of their environment (e.g. temperature, salinity, tidal mixing) have been investigated (e.g. Gosselin et al. 1985.
1986, 1990a, b, Bates \& Cota 1986, Cota et al. 1987, 1990, Cota \& Horne 1989, Cota \& Sullivan 1990). More recently, attention has been directed to the possible influence of dissolved nutrients on ice-algal growth and photosynthesis, spurred by evidence that: (1) population growth may be stimulated by the addition of nutrients to captured samples (Maestrini et al. 1986), (2) biochemical characteristics are often suggestive of nutrient-limited growth (Smith et al. 1987, Demers et al. 1989, Gosselin et al. 1990a, b), and (3) photosynthetic performance and other indices of physiological activity are positively correlated with tidally-induced mixing of nutrients at the ice-seawater interface (Gosselin et al. 1985, Cota et al. 1987, Cota \& Horne 1989 Demers et al. 1989), and/or other environmental forcing (Cota \& Sullivan 1990). Attention has initially focussed on the role of nitrogen because of its known importance as a limiting nutrient in plankton systems; detailed studies of the nitrogen nutrition of sea-ice algae have now been completed in both the Antarctic 
(Cota et al. 1988, Priscu et al. 1989, 1990), and the Arctic (this study) and sub-Arctic (Demers et al. 1989, Gosselin et al. 1990b).

We describe here the results of a 2 -season investigation of the nitrogen nutrition of ice-algal communities in Barrow Strait, Northwest Terrories (NWT), Canada with the main aims of documenting the magnitude and temporal variations in nitrogen utilization by the bottom-ice communities in relation to the population growth and decay cycle and, with this and information from ancillary experiments, addressing the question, 'is there compelling evidence for nitrogen limitation of sea-ice algal communities in Barrow Strait?'

\section{METHODS}

The study site was located on land-fast ice in Barrow Strait, NWT, Canada $\left(74^{\circ} 38^{\prime} \mathrm{N}, 94^{\circ} 54^{\prime} \mathrm{W}\right)$ about $4 \mathrm{~km}$ south of Cornwallis Island (Fig. 1). The area is described fully in Cota et al. (1987). Experimental work on nitrogen dynamics was concentrated during an approximate $3 \mathrm{wk}$ period in 1985 (17 May to 4 June) and an additional week in 1986 (5 to 12 May). Samples of the sea-ice bottom assemblages (Horner et al. 1988) were collected either daily (1986) or on alternate days (1985) in the morning by means of an ice auger from areas with moderate $(5$ to $12 \mathrm{~cm}$ ) snow cover. Samples were then transported to the adjacent ice camp laboratory where the loosely consolidated ice crystals from the bottom 'skeletal' layer (ca 3 to $5 \mathrm{~cm}$ thick) were carefully scraped into filtered (Whatman GF/F glass fiber filter) surface seawater and allowed to slowly melt (ca $-1.0^{\circ} \mathrm{C}$ ) in the dark. The resulting suspension was about $90 \%$ seawater and $10 \%$ melted ice with a salinity of about 30 ppt (Smith et al. 1987). Subsamples were then taken from the slurry for a variety of analyses including particulate matter (chlorophyll a, CHL: Holm-Hansen et al. 1965; organic carbon and nitrogen, POC, PON: Sharp 1974) and dissolved nutrients $\left(\mathrm{NO}_{3}{ }^{-}\right.$: Strickland \& Parsons 1972; $\mathrm{NH}_{4}{ }^{+}$: Solorzano 1969; urea: McCarthy 1970) from GF/F filtrates of the algal suspension and the surface seawater. Urea and $\mathrm{NO}_{3}{ }^{-}$ analyses were done on frozen samples, $\mathrm{NH}_{4}{ }^{+}$analyses were done on fresh samples within 1 to $2 \mathrm{~h}$ of collection. $\mathrm{NH}_{4}^{+}$analyses were also done subsequently on the frozen samples (as part of the urease-urea analysis) and gave values similar to those from the fresh samples, suggesting no serious contamination problem arising from the freezing and storage process (see also

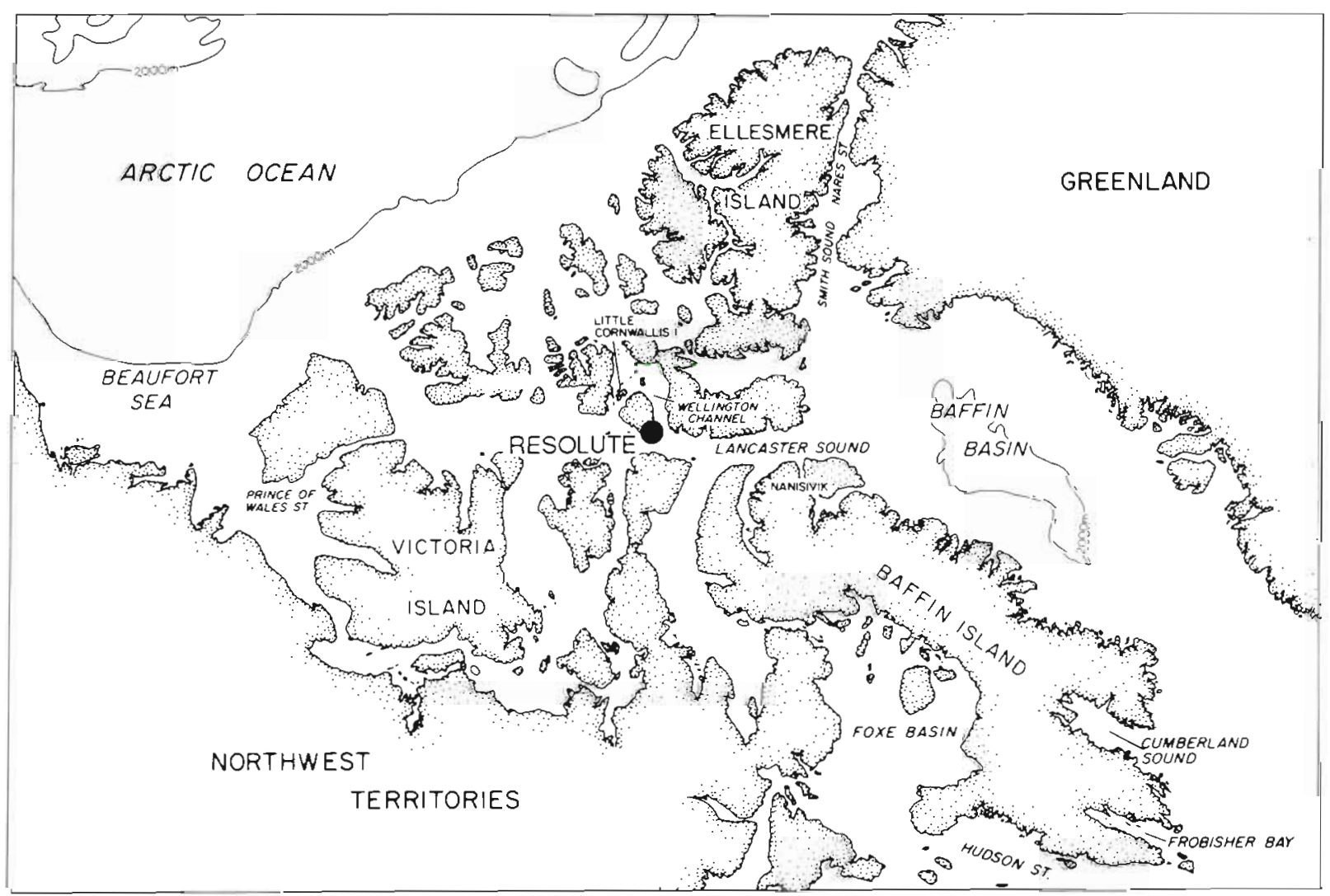

Fig. 1 Study site in Barrow Strait. Northwest Territories, Canada. Ice camps were located ca $4 \mathrm{~km}$ to the south of Resolute 
Smith et al. 1990). Corrections were made for the dilution effect of the added seawater:

$$
\mathrm{C}_{\mathrm{a}}=\left[\left(\mathrm{C}_{\mathrm{m}} \mathrm{V}_{\mathrm{m}}\right)-\left(\mathrm{C}_{\mathrm{s}} \mathrm{V}_{\mathrm{s}}\right)\right] / \mathrm{V}_{\mathrm{a}}
$$

where $\mathrm{C}$ and $\mathrm{V}=\mathrm{N}$-concentration and sample volume of the undiluted ice algae (a), filtered seawater (s), and ice algae-seawater mixture $(\mathrm{m})$, respectively. During both the 1985 and 1986 sampling periods, concentrations of $\mathrm{NO}_{3}{ }^{-}, \mathrm{NH}_{4}{ }^{+}$, and urea in the surface seawater (diluent) were on average 3 to 6,0 to 0.2 and 0 to $0.2 \mu \mathrm{mol} \mathrm{N} \mathrm{^{-1 }}$, respectively (see also Cota et al. 1990).

Nitrogen-15 labelled tracers (95 to 99 atom \% enriched) were employed for the measurements of $\mathrm{NO}_{3}{ }^{-}$(as $\mathrm{K}^{15} \mathrm{NO}_{3}$ ), $\mathrm{NH}_{4}{ }^{+}$(as ${ }^{15} \mathrm{NH}_{4} \mathrm{Cl}$ ) and urea uptake by the algal communities in the dilute suspensions. Isotopes were added to a final concentration of 1 to $10 \mu \mathrm{mol} \mathrm{N} \mathrm{l}^{-1}$. These additions were usually small compared to the ambient concentrations (see below) and therefore likely did not perturb (i.e. enhance) the in situ uptake rates. Incubations ( $\sim 20 \mathrm{ml}$ of algal suspension) were carried out in acid-cleaned glass scintillation vials for $1 \mathrm{~h}$ in blue-filtered, artificial light incubators maintained at ambient temperature and at an irradiance level of $6.5 \mu \mathrm{E} \mathrm{m}^{-2} \mathrm{~s}^{-1}$ (Smith et al 1987). Incubations were terminated by gentle vacuum filtration $(<100$ $\mathrm{mm} \mathrm{Hg}$ ) of the particulates onto precombusted $\mathrm{GF} / \mathrm{F}$ glass fiber filters. The filters were subsequently dried and analyzed for nitrogen isotope ratios by emission spectrometry (Fiedler \& Proksch 1975). Uptake rates were calculated according to the equations of Dugdale \& Goering (1967); no corrections were made for 'isotope dilution' in the $\mathrm{NH}_{4}{ }^{+}$experiments (Glibert et al. 1982). Corrections to uptake rates (mass volume ${ }^{-1}$ ) were made for seawater dilution effects using a formulation similar to Eq. (1) by assuming no contribution to the uptake from the filtered seawater diluent and assuming that uptake rates were substrate 'saturated' before as well as after the dilution step (see below). On a few occasions during the 1985 study, a commercial mixture of algal amino acids labelled with nitrogen-15 (MSD Isotopes) was included in the standard experimental protocol, however, since amino acid substrate concentrations were not measured, quantitative estimates of uptake rates was not possible. On other occasions in 1985, the concentration-dependence of $\mathrm{NO}_{3}{ }^{-}, \mathrm{NH}_{4}{ }^{+}$and urea uptake were measured as well as the response of $\mathrm{NO}_{3}{ }^{-}$and $\mathrm{NH}_{4}{ }^{+}$uptake rates to light level in a light-gradient incubator. Details of this experimental apparatus are given in Cota (1985)

In 1986, daily measurements of nitrate reductase (EC 1.6.6.2) activity (NR) supplemented the nitrogen-15 tracer measurements. The cell-permeabilizing procedure of Hochman et al. (1986) was used on cells concentrated on GF/F glass filters; triplicate controls (no added NADH) and treatments were run. This proce- dure gave activity levels 3 -fold higher than the grinding method often used in plankton studies (Eppley et al. 1969a); enzyme activity, nonetheless, accounted for only $\sim 20 \%$ of the uptake based on our ${ }^{15} \mathrm{NO}_{3}{ }^{-}$tracer measurements but this is not unexpected for crude enzyme extracts (Eppley et al. 1969a). Incubations were for $1 \mathrm{~h}$ (over which time $\mathrm{NO}_{2}^{-}$production was linear) and done at ambient temperature $\left(\sim-1.0^{\circ} \mathrm{C}\right)$. Activity was an order of magnitude higher at ambient than at room temperature $\left(\sim 20^{\circ} \mathrm{C}\right.$ ) (see also Priscu et al. 1989). Coefficients of variation (CV) for replicate determinations averaged less than $15 \%$. Early attempts were made to measure enzyme activity on directly melted ice algal samples, however, rates were less than half those from samples melted in seawater (standard protocol) and the direct-melt procedure was therefore abandoned (see also Bates \& Cota 1986, Garrison \& Buck 1986).

\section{RESULTS}

The time periods over which these studies were done emcompassed both the early phase of increasing CHL biomass (1986) and the declining CHL biomass phase (1985) of the annual ice-algal growth cycle (Fig. 2a; a more complete treatment of seasonal CHL dynamics is given by Smith et al. 1988). Although day-to-day variability was large, a similar pattern was seen in the $\mathrm{NO}_{3}{ }^{-}$ concentration of the melted bottom ice, i.e. concentrations often exceeding $100 \mu \mathrm{mol} \mathrm{N} \mathrm{N}^{-1}$ were observed during the early growth phase in 1986 with significantly lower concentrations seen during the algal decline phase in 1985 (Fig. 2b). Most noteworthy about the $\mathrm{NH}_{4}{ }^{+}$concentrations was a rapid increase on the last sampling date in 1985 when biomass was on the decline (Fig. 2c).

The dynamics of the CHL biomass and nutrients were reflected in the utilization of $\mathrm{NO}_{3}$ and $\mathrm{NH}_{4}{ }^{+}$by bottom-ice assemblages. $\mathrm{NO}_{3}^{-}$uptake was substantially higher in 1986 than in 1985, attaining rates as high as $80 \mu \mathrm{mol} \mathrm{N} \mathrm{l}^{-1} \mathrm{~h}^{-1}$; rates generally decreased with time in 1985 and increased with time in 1986 as did biomass (Table 1). $\mathrm{NH}_{4}{ }^{+}$uptake rates, on the other hand, tended to increase with time in both 1985 and 1986; in $1986 \mathrm{NO}_{3}{ }^{-}$uptake exceeded $\mathrm{NH}_{4}{ }^{+}$uptake at most samplings whereas $\mathrm{NH}_{4}{ }^{+}$uptake exceed $\mathrm{NO}_{3}{ }^{-}$ uptake at the latter samplings of 1985 . With few exceptions, $\mathrm{NH}_{4}{ }^{+}$was the preferred form used when compared with its relative concentration $\left(\mathrm{RPI}_{\mathrm{NH}_{4}}>1\right.$, Table 1). The pattern of a shift from predominantly $\mathrm{NO}_{3}{ }^{-}$metabolism during the algal growth phase to $\mathrm{NH}_{4}{ }^{+}$metabolism during decline is clearly seen when the f-ratio $\left[\mathrm{NO}_{3}{ }^{-}\right.$uptake/ $\left(\mathrm{NO}_{3}{ }^{-}+\mathrm{NH}_{4}{ }^{+}\right)$uptake] is plotted against time (Fig, 2d). In addition to tracer mea- 

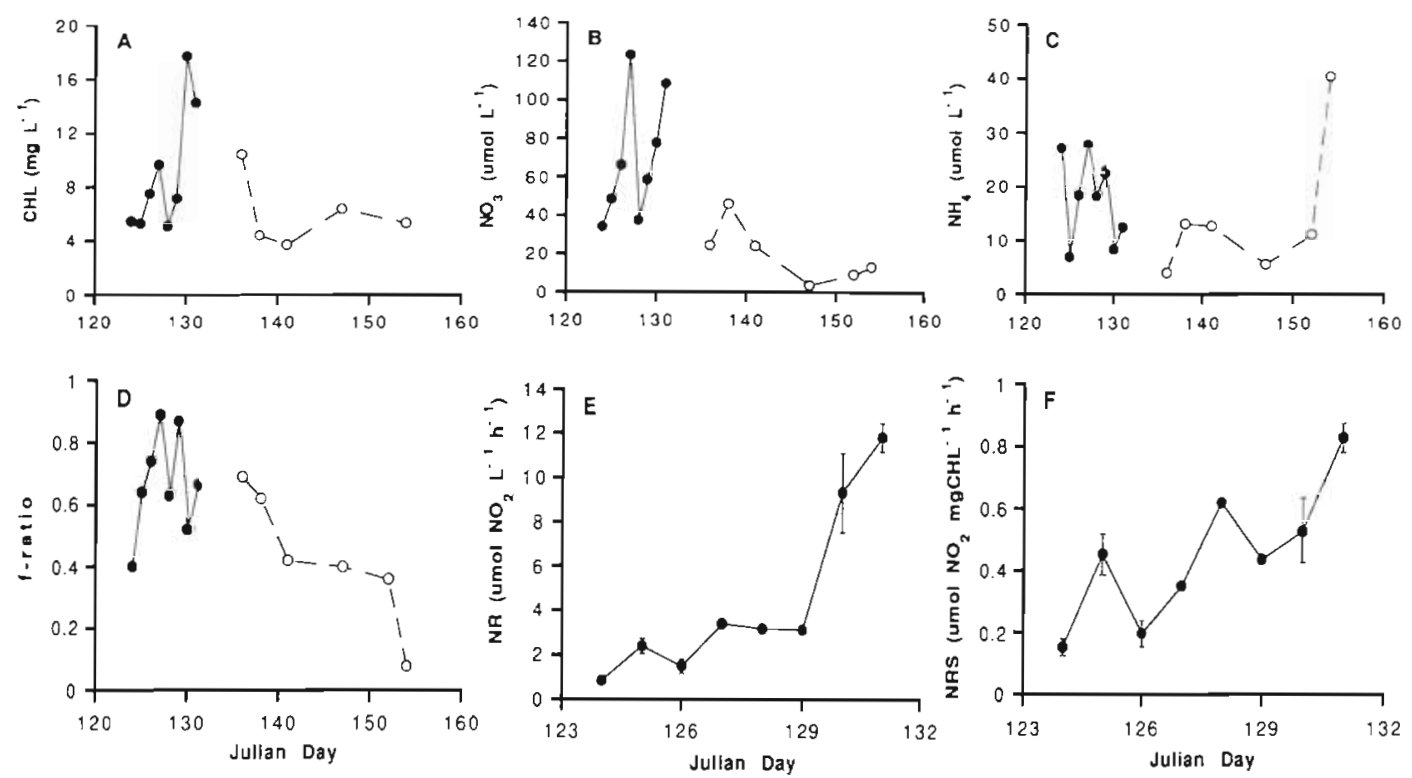

Fig. 2. Temporal variations in bottom-ice chlorophyll a (CHL), nutrients $\left(\mathrm{NO}_{3}{ }^{-}, \mathrm{NH}_{4}{ }^{+}\right)$, f-ratio, and nitrate reductase activity ( $\mathrm{NR}$, NRS) during 1985 and 1986. $\mathrm{CHL}=\mathrm{mg} \mathrm{l}{ }^{-1} ; \mathrm{NO}_{3}{ }^{-}, \mathrm{NH}_{4}{ }^{+}=\mu \mathrm{mol} \mathrm{N} \mathrm{I}{ }^{-1} ;$ f-ratio $=\left[\mathrm{NO}_{3}{ }^{-}\right.$uptake $/\left(\mathrm{NO}_{3}{ }^{-}+\mathrm{NH}_{4}{ }^{+}\right)$uptake $] ; \mathrm{NR}^{-}=\mu \mathrm{mol}$ $\mathrm{NO}_{2}^{-} \mathrm{l}^{-1} \mathrm{~h}^{-1}$; $\mathrm{NRS}=$ mol $\mathrm{NO}_{2}^{-} \mathrm{mgCHL}^{-1} \mathrm{~h}^{-1}$ Filled circles/solid lines are $1986 \mathrm{data}$, open circles/dashed lines are $1985 \mathrm{data}$. Vertical bars are \pm 1 standard deviation

surements, the activity of the $\mathrm{NO}_{3}{ }^{-}$assimilatory enzyme, nitrate reductase (NR), was monitored in 1986. NR activity increased with time, even when normalized to chlorophyll biomass (Fig. 2e, f), supporting evidence from the tracer data of the importance of $\mathrm{NO}_{3}{ }^{-}$utilization during this stage of the growth cycle. Moreover, NR activity showed little sensitivity (i.e. inhibition or enhancement) to sample enrichment with $\mathrm{NH}_{4}{ }^{+}$or $\mathrm{NO}_{3}{ }^{-}$(Table 2).
During the 1985 studies, measurements were also made of the concentrations and uptake of urea. Surprisingly, urea concentrations of the melted bottom ice often exceeded those of $\mathrm{NH}_{4}{ }^{+}$, however, uptake rates of the bottom-ice assemblages were only about half the $\mathrm{NH}_{4}{ }^{+}$uptake rates (Table 1). Nonetheless, urea represented about $22 \%$ of the total $\left(\mathrm{NO}_{3}{ }^{-}+\mathrm{NH}_{4}{ }^{+}+\right.$urea) nitrogen utilized. Normalizing the utilization rates of the various forms of nitrogen to the dissolved and

Table 1. Nitrogen utilization rates by sea-ice algal assemblages in Barrow Strait, Northwest Territories, Canada. CHL =

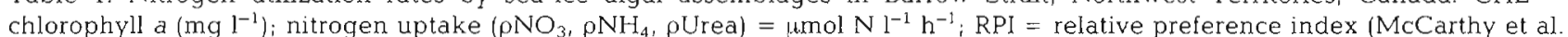
$1977)$, where e.g. $\mathrm{RPI}_{\mathrm{NO}_{3}}=\left[\rho \mathrm{NO}_{3} / \rho\right.$ TotalN $] /\left[\mathrm{NO}_{3}\right.$ Conc./TotalN Conc. $]$, etc

\begin{tabular}{|c|c|c|c|c|c|c|c|}
\hline Date/Julian day & CHL & $\rho \mathrm{NO}_{3}$ & $\rho \mathrm{NH}_{4}$ & $\rho$ Urea & $\mathrm{RPI}_{\mathrm{NO}}{ }^{a}$ & $\mathrm{RPI}_{\mathrm{NH}_{4}^{\mathrm{d}}}^{\mathrm{d}}$ & $\mathrm{RPI}_{\text {Urea }}$ \\
\hline \multicolumn{8}{|l|}{ (1985) } \\
\hline 17 May/137 & 10.45 & 10.53 & 4.64 & 2.33 & 1.02 & 2.66 & 0.66 \\
\hline 19 May/139 & 4.45 & 4.25 & 2.64 & 5.37 & 0.81 & 1.77 & 0.97 \\
\hline $22 \mathrm{May} / 142$ & 3.74 & 3.08 & 4.29 & 4.67 & 0.60 & 1.57 & 1.13 \\
\hline $28 \mathrm{May} / 148$ & 6.41 & 9.73 & 14.70 & & 0.98 & 1.02 & \\
\hline 02 June/153 & & 3.00 & 5.32 & 2.00 & 1.72 & 2.41 & 0.32 \\
\hline 04 June/155 & 5.38 & 0.87 & 10.05 & 2.41 & 0.69 & 2.46 & 0.31 \\
\hline \multicolumn{8}{|l|}{$(1986)$} \\
\hline $05 \mathrm{May} / 125$ & 5.46 & 7.94 & 11.84 & & 0.72 & 1.36 & \\
\hline $06 \mathrm{May} / 126$ & 5.30 & 6.99 & 3.97 & & 0.73 & 2.87 & \\
\hline $07 \mathrm{May} / 127$ & 7.52 & 23.87 & 8.40 & & 0.95 & 1.19 & \\
\hline $08 \mathrm{May} / 128$ & 9.68 & 80.04 & 9.51 & & 1.10 & 0.58 & \\
\hline 09 May/129 & 5.11 & 7.24 & 4.17 & & 0.94 & 1.12 & \\
\hline 10 May/130 & 7.17 & 29.79 & 4.42 & & 1.21 & 0.46 & \\
\hline 11 May/131 & 17.73 & 38.62 & 36.15 & & 0.57 & 4.98 & \\
\hline $12 \mathrm{May} / 132$ & 14.27 & 59.45 & 30.98 & & 0.73 & 3.32 & \\
\hline
\end{tabular}


Table 2. Effects of $\mathrm{NO}_{3}{ }^{-}$and $\mathrm{NH}_{4}{ }^{+}$additions $\left(10 \mu \mathrm{mol} \mathrm{N}{ }^{-1}\right)$ on nitrate reductase activity of sea-ice algae. Protocol for enzyme assay described in 'Methods' Samples to test effects of $\mathrm{NH}_{4}{ }^{+}$ ( $\mathrm{SW}, \mathrm{SW}+\mathrm{NH}_{4}{ }^{+}$) were prepared as described in 'Methods', i.e. melted in filtered seawater (dilution $\sim 17: 1$ ); initial $\mathrm{NO}_{3}{ }^{-}$ and $\mathrm{NH}_{4}{ }^{+}$concentrations of diluted samples were 3.83 and $0.72 \mu \mathrm{mol} \mathrm{l} \mathrm{l}^{-1}$, respectively. Samples to test $\mathrm{NO}_{3}{ }^{-}$effects $(\mathrm{AQ}$, $\mathrm{AQ}+\mathrm{NO}_{3}{ }^{-}$), because of the high residual $\mathrm{NO}_{3}{ }^{-}$in the dilution seawater, were melted in 'synthetic' seawater (Aquil ${ }^{(*)}$, Morel et al. 1979) with nitrogen excluded dilution was $\sim 13: 1$ and initial $\mathrm{NO}_{3}{ }^{-}$and $\mathrm{NH}_{4}{ }^{+}$concentrations of diluted samples were 0.48 and $0.47 \mu \mathrm{mol} \mathrm{l}^{-1}$, respectively. After $\sim 23 \mathrm{~h}, 1.43 \mu \mathrm{mol} \mathrm{l}{ }^{-1}$ of $\mathrm{NH}_{4}^{+}$and $4.49 \mu \mathrm{mol} \mathrm{l}{ }^{-1}$ of $\mathrm{NO}_{3}^{-}$remained in the $\mathrm{N}$. supplemented samples ( $\mathrm{SW}+\mathrm{NH}_{4}{ }^{+}$and $\mathrm{AQ}+\mathrm{NO}_{3}{ }^{-}$, respectively). Nitrate reductase activity in units of $\mu \mathrm{mol} \mathrm{NO}_{2}^{-}$ $\mathrm{mgCHL}^{-1} \mathrm{~h}^{-1}$

\begin{tabular}{|ccccc|}
\hline Incubation time (h) & $\mathrm{AQ}$ & $\mathrm{AQ}^{2}+\mathrm{NO}_{3}{ }^{-}$ & $\mathrm{SW}$ & $\mathrm{SW}+\mathrm{NH}_{4}{ }^{+}$ \\
\hline 0.0 & 0.200 & 0.200 & 0.829 & 0.829 \\
1.3 & 0.200 & 0.272 & 0.511 & 0.753 \\
3.1 & 0.381 & 0.423 & 1.201 & 1.109 \\
8.8 & 0.502 & 0.650 & 1.016 & 0.885 \\
23.1 & 0.465 & 0.638 & 0.541 & 0.393 \\
Mean: & 0.350 & 0.437 & 0.820 & 0.794 \\
\hline
\end{tabular}

particulate pools revealed that the cycling of nitrogen in the ice-algal communities was rapid (Table 3 ). Despite large pools of dissolved and particulate nitrogen (compared to what is typically found in planktonic systems), turnover times of dissolved- $\mathrm{N}$ ranged from as short as $<1 \mathrm{~h}$ (in the case of $\mathrm{NH}_{4}{ }^{+}$) to $>1 \mathrm{~d}$ (urea); particulate nitrogen ( $\mathrm{PON}$ ) turnover times ranged from about 1 to $8 \mathrm{~d}$. PON and $\mathrm{NO}_{3}{ }^{-}$turnover times were shorter in 1986 than in 1985 while turnover times for $\mathrm{NH}_{4}{ }^{+}$were comparable for the $2 \mathrm{yr}$.

Additional experiments were performed in 1985 to investigate other physiological properties of the nitrogen nutrition of the bottom-ice assemblages. Measurements of the response to a light gradient on 2 occasions revealed no apparent light-dependence in the uptake of $\mathrm{NO}_{3}{ }^{-}$or $\mathrm{NH}_{4}{ }^{+}$over a range of light intensities from 0 to $125 \mu \mathrm{E} \mathrm{m}^{-2} \mathrm{~s}^{-1}$ (Fig. 3) which span natural conditions. Concentration-dependent uptake kinetics were also determined for $\mathrm{NO}_{3}{ }^{-}, \mathrm{NH}_{4}{ }^{+}$and urea on one occasion (20 May, Julian Day 140); half-saturation constants ( $\mathrm{K}_{\mathrm{s}}$ in units of $\mu \mathrm{mol} \mathrm{N} \mathrm{l}^{-1} \pm 95 \%$ confidence limits) were $1.60 \pm 0.25$ and $0.94 \pm 0.34$ for $\mathrm{NH}_{4}{ }^{+}$and urea respectively. Ambient $\mathrm{NO}_{3}^{-}$concentrations were too high to permit an estimate of $K_{s}$, i.e. uptake rate was saturated at the $\sim 4 \mu \mathrm{mol} \mathrm{N}{ }^{-1}$ ambient level, thus the $\mathrm{K}_{\mathrm{s}}$ would have been lower than this value.

A single experiment was performed during the 1985 study in an attempt to differentiate the contributions of prokaryotic and eukaryotic components of the bottom community to the uptake of $\mathrm{NO}_{3}{ }^{-}, \mathrm{NH}_{4}{ }^{+}$, urea and a mixture of algal amino acids. Chloramphenicol and
Table 3. Turnover times for various nitrogen pools

\begin{tabular}{|c|c|c|c|c|}
\hline \multirow[t]{2}{*}{ Year } & \multirow[t]{2}{*}{ Pool } & \multirow[t]{2}{*}{ No. } & \multicolumn{2}{|c|}{ Turnover time } \\
\hline & & & (Range) & (Mean) \\
\hline \multirow[t]{4}{*}{1985} & $\mathrm{PON}^{*}$ & 5 & $3.12-8.20$ & $6.18 \mathrm{~d}$ \\
\hline & $\mathrm{NO}_{3}^{-}$ & 6 & $0.42-15.32$ & $6.65 \mathrm{~h}$ \\
\hline & $\mathrm{NH}_{4}{ }^{+}$ & 6 & $0.39-5.00$ & $2.56 \mathrm{~h}$ \\
\hline & Urea & 5 & $4.10-32.94$ & $14.36 \mathrm{~h}$ \\
\hline \multirow[t]{3}{*}{1986} & PON & 8 & $1.29-5.76$ & $2.76 \mathrm{~d}$ \\
\hline & $\mathrm{NO}_{3}^{-}$ & 8 & $1.83-6.95$ & $2.51 \mathrm{~h}$ \\
\hline & $\mathrm{NH}_{4}^{+}$ & 8 & $0.40-5.08$ & $2.61 \mathrm{~h}$ \\
\hline
\end{tabular}
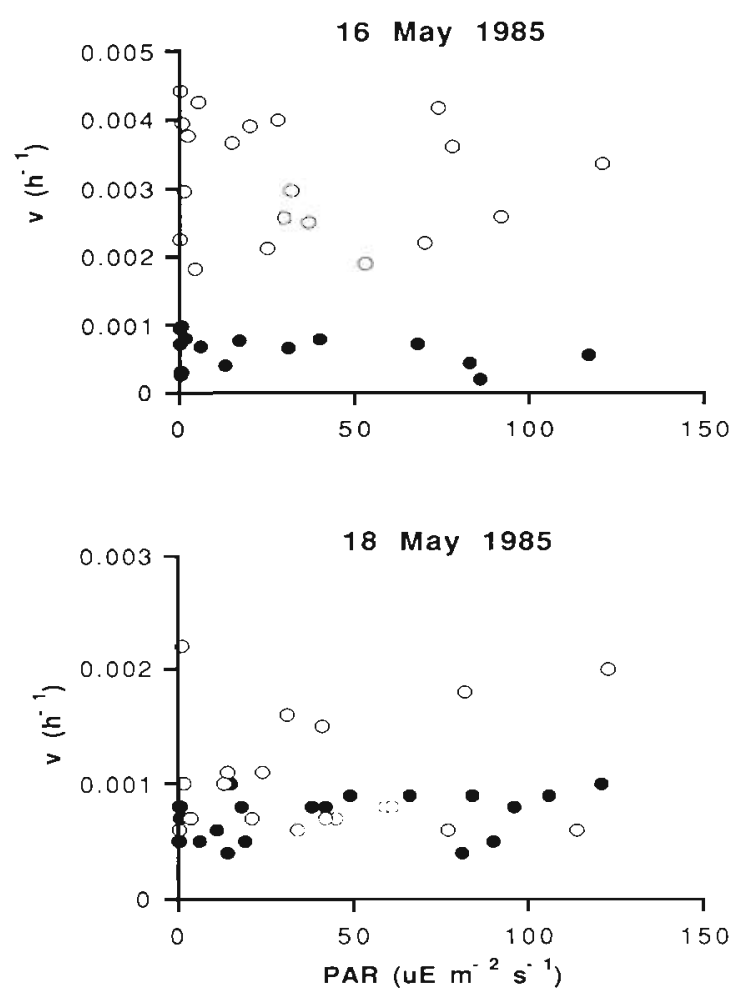

Fig. 3. Effects of light intensity on specific uptake rate $\left(\mathrm{v}, \mathrm{h}^{-1}\right)$ of $\mathrm{NO}_{3}{ }^{-}$and $\mathrm{NH}_{4}{ }^{+}, 1985$ study (16, 18 May, Julian Days 136, 138). Experimental procedure followed that described by Cota (1985) using the 'photosynthetron' (Lewis \& Smith 1983), light gradient incubator. Ambient light levels reaching the ice algae were in the range 1 to $10 \mu \mathrm{E} \mathrm{m}^{-2} \mathrm{~s}^{-1}$ (Smith et al. 1988)

cycloheximide were used as specific inhibitors of prokaryotic and eukaryotic nitrogen metabolism, respectively. Results suggested that a significant portion of the $\mathrm{NH}_{4}{ }^{+}$and amino acid uptake may have been mediated by prokaryotes; $\mathrm{NO}_{3}{ }^{-}, \mathrm{NH}_{4}{ }^{+}$and urea up:ake appeared equally affected by the eukaryote inhibitor while amino acid uptake was relatively unaffected (Fig. 4). 


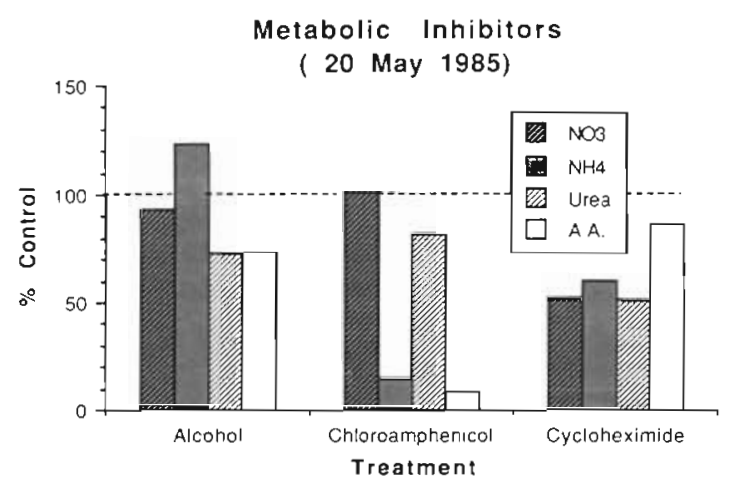

Fig. 4. Effects of metabolic inhibitors on the uptake of ${ }^{15} \mathrm{~N}$ labelled $\mathrm{NO}_{3}{ }^{-}, \mathrm{NH}_{4}{ }^{+}$, urea and amino acids (20 May 1985 , Julian Day 140). Treatments included: controls (no inhibitors) and alcohol (ethanol carrier and control for chloramphenicol, $0.3 \%$ by volume final addition), chloramphenicol (prokaryote inhibitor, $\sim 100 \mathrm{mmol} \mathrm{l}^{-1}$ final concentration), and cycloheximide (eukaryote inhibitor, $\sim 100 \mu \mathrm{mol} \mathrm{l}^{-1}$ final concentration). After $1 \mathrm{~h}$ inhibitor pretreatment, samples were incubated for an additional $3 \mathrm{~h}$ following additions $\left(10 \mu \mathrm{mol} \mathrm{N} \mathrm{I}^{-1}\right)$ of ${ }^{15} \mathrm{~N}$ tracer; incubations followed 'standard protocol' (see 'Methods')

\section{DISCUSSION}

We observed, coincident with the annual cycle of growth and subsequent decline in sea-ice algal biomass in Barrow Strait, a systematic shift from predominantly $\mathrm{NO}_{3}{ }^{-}$metabolism during the early growth stage to predominantly $\mathrm{NH}_{4}{ }^{+}$metabolism during the algal population decline. Considering that the major source of $\mathrm{NO}_{3}{ }^{-}$(and 'new' production, sensu Dugdale \& Goering 1967 ) in this environment is provided by physical processes whereas $\mathrm{NH}_{4}{ }^{+}$(and 'regenerated' production) is derived largely from in situ biological metabolism (Cota et al. 1987), it seems clear that the conceptual model for the cycling of nitrogen in the pelagic ocean and its relation to primary production (Dugdale 1967, Dugdale \& Goering 1967) holds also for sea-ice bottom communities. The dominance of $\mathrm{NO}_{3}{ }^{-}$. based production when algal biomass accumulates was also evident in our 1986 study based on the progressive increase over the sampling period in nitrate reductase (NR) activity. NR specific activity (normalized to CHL) was similar to levels found in planktonic algae but differed in its apparent insensitivity to high ambient $\mathrm{NH}_{4}{ }^{+}$concentrations (Eppley et al. 1959a).

Similar temporal patterns, i.e. progressive shifts from the predominance of 'new' to 'regenerated' nitrogen nutrition as the growth season progresses, have been documented recently in Hudson Bay (Gosselin et al. 1990b). Grossi et al. (1987) and Cota \& Sullivan (1990) in the Antarctic and Smith et al. (1988) in the Arctic recently calculated an excess of ${ }^{14} \mathrm{C}$-based primary production over observed biomass accumulation in the ice, which was stated to imply either an export from the ice or consumption within the ice, or both. Our low fratios late in the growth season suggested that consumption within the ice not only occurred but may have been the dominant loss term. High f-ratios early in the growth season would be indicative of export if current conceptual models (Eppley \& Peterson 1979) are applicable to sea-ice communities. For 1985, Smith et al. (1988) estimated that 20 to $50 \%$ of the seasonal primary production under thin snow covers was exported or consumed; this matches reasonably well with the f-ratios we observed (with the exception of the last sampling point). For 1986, Smith et al. (1988) estimated the loss to be on the order of $70 \%$; this suggests losses higher than inferred from our f-ratios but this would include events much later in the season, when the f-ratios would presumably be lower than we measured and more like the 1985 values. These results suggest that the role nitrogen plays in the integrity of the under-ince communities late in the growth season may be less dependent on physical forcing (Cota et al. 1987. Cota \& Horne 1989) and more so on community structure/metabolism. It is apparent, for example, that microheterotrophs (bacteria) and grazers which feed on the sea ice algae (and constitute the major source of 'regenerated' nutrients) increase in abundance and relative importance over the growth season (Grossi et al. 1984, Carey 1985, Smith et al. 1989a; see also Cota et al. 1987). Some portion, however, of the regenerated' nutrients may be channeled directly back into the heterotrophs and specifically into the prokaryotes (bacteria) based on the results of our single metabolic inhibitor experiment. This may not be surprising when considering the low molecular weight organics, i.e. amino acids, but has only recently been documented for inorganic-N, i.e. $\mathrm{NH}_{4}{ }^{+}$(Wheeler \& Kirchman 1986). Although our results did imply that prokaryotes dominate the metabolism of amino acids, other studies suggest an important role by eukaryotes (Rivkin \& Putt 1987, R.E.H. Smith unpubl.). Our findings based on such limited data therefore should be interpreted with caution. The seasonal dynamics of heterotrophic utilization of inorganic- $\mathrm{N}$ in sea ice communities, whether by prokaryotes or eukaryotes, is poorly understood at present.

Our experiments to investigate the effects of light on nitrogen uptake revealed that both $\mathrm{NO}_{3}{ }^{-}$and $\mathrm{NH}_{4}{ }^{+}$ uptake were apparently light independent in shortterm (1 h) incubations. Cota et al. (1988) and Priscu et al. (1990), by contrast, did detect a light-dependent response of $\mathrm{NO}_{3}^{-}$and $\mathrm{NH}_{4}{ }^{+}$uptake in antarctic ice algae, although uptake in the dark was significant and saturation light intensities were near ambient as is characteristic of the photosynthetic response of sea ice algae in both polar oceans (e.g. Cota 1985, Palmisano et al. 1985, Michel et al. 1988) 
Results from our few kinetics experiments suggest that the substrate concentration-dependence of $\mathrm{N}$ uptake resembles that for coastal planktonic algae (Eppley et al. 1969b), i.e. $\mathrm{K}_{\mathrm{s}}$ on the order $1 \mu \mathrm{mol} \mathrm{N} \mathrm{N}^{-1}$. Considering the fact that substrate concentrations were generally 1 to 2 orders of magnitude greater than this, it is unlikely that uptake rates of nitrogenous compounds were regulated by nutrient level during our 1985 or 1986 experiments. Nitrogen limitation may be of some importance earlier in the growth cycle when bottom-ice nutrients are much lower (Cota et al. 1990). A potential complication in this interpretation, however, arises from recent observations of a strong correlation between skeletal-layer dissolved nitrogen and algal chlorophyll a (Cota et al. 1990. Smith et al. 1990), suggesting that some (possibly significant) portion of what we describe as 'substrate' nitrogen may have in fact been intracellular nitrogen pools which leaked from the algal cells during the process of melting the ice and filtration of the particulates.

Regardless of whether the high concentrations of $\mathrm{NO}_{3}{ }^{-}, \mathrm{NH}_{4}{ }^{+}$and urea were external to the cell or internal, the implication remains that the algal assemblages never appeared to be nitrogen-limited; the kinetics argue that uptake is always 'saturated' and if the observed nutrient levels represented to some extent internal pools, levels are equivalent to those generally reported for nutrient-sufficient cells (Cota et al. 1990, Smith et al. 1990). Gosselin et al. (1990b) came to similar conclusions from studies in Hudson Bay. Biochemical evidence from our studies also argues against nitrogen limitation: particulate organic carbon (POC)/CHL ratios $(\mathrm{g} / \mathrm{g})$ were $35 \pm 6(1 \mathrm{SD})$ and $20 \pm 2$ in 1985 and 1986, respectively and POC/PON ratios (atomic) were $8.8 \pm 0.4$ and $6.7 \pm 1.6$, all well within the range characteristic of nitrogen-sufficient cells (e.g. Goldman 1980, Laws \& Bannister 1980). In addition, growth rates estimated from our short-term $\mathrm{N}$-uptake measurements were similar to estimates based on CHL and particulate carbon from previous years (Table 4) and are consistent with those reported for nutrient-sufficient, temperature-limited cells (Eppley 1972)

There still remains the question of the role of nutrients in the well-documented fluctuations between ice algal photosynthetic activity and the physical forcing associated with the fortnightly tidal cycles (Gosselin et al. 1985, Cota et al. 1987, Cota \& Horne 1989, Demers et al. 1989) and other environmental variability (Cota \& Sullivan 1990). The results described here, as well as for other polar regions (Cota \& Sullivan 1990, Gosselin et al. 1990a, b) certainly argue for less emphasis on nitrogen. Recent evidence now points to silicon as a potential limiting nutrient (Cota \& Sullivan 1990, Cota et al. 1990, Gosselin et al. 1990a, b). Silicon, as silicic acid, is not highly concentrated in colonized bottom ice, unlike soluble reactive phosphorus $\left(\mathrm{PO}_{4}{ }^{3-}\right.$ ) and nitrogen $\left(\mathrm{NO}_{3}{ }^{-}\right)$which show accumulations proportional to algal biomass (Cota et al. 1990). Welch \& Bergmann (1989) found significant Si-depletion over the upper $100 \mathrm{~m}$ in Barrow Strait well before phytoplankton blooms (also see Cota et al. 1990). Seasonal patterns in biochemical composition suggest that silicon becomes limiting during the later stages of ice algal blooms (Gosselin et al. 1990a). Bioassays in nonbrackish waters of Hudson Bay revealed stimulation of growth only by silicic acid (Gosselin pers. comm.). Moreover, dissolution of biogenic silicon in polar waters is relatively slow (e.g. Nelson \& Gordon 1982) compared to phosphorous and nitrogen regeneration

Table 4. Estimated or measured biomass, nitrogen requirements and growth rates of ice-algal assemblages, Barrow Strait, Northwest Territories, Canada. Chlorophyll a $(\mathrm{CHL})=\mathrm{mg} \mathrm{m}^{-2}, \mathrm{~N}$-uptake $=$ mmol $\mathrm{N} \mathrm{m}^{-2} \mathrm{~d}^{-1}$, growth rate $=\mathrm{d}^{-1}$

\begin{tabular}{|c|c|c|c|c|c|c|c|c|c|c|}
\hline \multirow[t]{2}{*}{ Time period } & \multicolumn{3}{|c|}{$\mathrm{CHL}$} & \multicolumn{3}{|c|}{ N-uptake } & \multicolumn{3}{|c|}{ Growth rate ${ }^{a}$} & \multirow[t]{2}{*}{ Source } \\
\hline & $\#$ & Range & Mean & $\#$ & Range & Mean & $\#$ & Range & Mean & \\
\hline $\begin{array}{l}\text { 07 Apr-06 Jun } \\
\text { (1983) }\end{array}$ & 21 & $0.0-52.3$ & 7.6 & 14 & $0.00-14.57$ & 0.68 & 14 & $0.01-0.78$ & 0.24 & Cota et al. (1987) \\
\hline $\begin{array}{l}17 \mathrm{Apr}-06 \mathrm{Jun} \\
(1984)\end{array}$ & 63 & $1.4-79.8$ & 18.3 & 30 & $0.01-5.13$ & 0.52 & 30 & $0.01-0.18$ & 0.08 & Cota et al. (1987) \\
\hline $\begin{array}{l}\text { 17 May-04 Jun } \\
\text { (1985) }\end{array}$ & 5 & $37.4-104.5$ & 60.9 & 6 & $1.65-5.86$ & 2.92 & 5 & $0.12-0.32$ & 0.18 & This study \\
\hline $\begin{array}{l}\text { 05 May-12 May } \\
\text { (1986) }\end{array}$ & 8 & $51.1-177.3$ & 107.9 & 8 & $2.63-21.70$ & 14.42 & 8 & $0.17-0.78$ & 0.45 & This study \\
\hline \multicolumn{11}{|c|}{$\begin{array}{l}\text { "Cota et al. (1987) estimated growth rate from net positive changes in cell number or carbon biomass over time. Our growth } \\
\text { rates are based on N-uptake measurements (daily rates }=\text { hourly rates } \times 24 \text { ), i.e growth rate }=N \text {-uptake/PON, and are } \\
\text { somewhat higher as might be expected since short-term N-uptake would more likely measure 'gross' rather than 'net' } \\
\text { uptake. Regression analysis (PON versus CHI) suggested a minor contribution of detritus to the PON, i.e. the regression } \\
\text { intercept on the PON axis represented }<5 \% \text { of the average PON level observed }\end{array}$} \\
\hline
\end{tabular}


(Harrison 1980). Furthermore, nutrient uptake experiments on antarctic phytoplankton (Sommer 1986) and ice algae (Cota et al. unpubl.) show that half-saturation constants for silicic acid are amongst the highest ever noted and may even exceed the high ambient concentrations.

Recently refined approaches for studying the vertical fine structure in the bottom-ice assemblages and their micro-environments (Smith et al. 1990) will also be of considerable value in helping to elucidate how nutrients supplied by physical and biological process are involved in the production cycle of bottom ice communities.

Acknowledgements. The authors acknowledge financial support from the Federal Department of Fisheries and Oceans (DFO), the Natural Sciences and Engineering Research Council of Canada (NSERC), the Office of Energy Research and Development (OERD), and logistical support from the Polar Continental Shelf Project (PCSP). L. Harris, P. Hunter, L. Wood and J. Spry assisted in sample collection and nutrient and stable isotope analysis. Three anonymous reviewers provided helpful comments on an earlier version of this manuscript.

\section{LITERATURE CITED}

Bates, S. S., Cota, G. F. (1986). Fluorescence induction and photosynthetic responses of arctic ice algae to sample treatment and salinity. J. Phycol. 22: 421-429

Carey, A. G. (1985). Marine ice fauna: arctic. In: Horner, R. A. (ed.) Sea ice biota. CRC Press, Boca Raton, Fla, p. 173-190

Conover, R. J., Cota, G. F., Harrison, W G., Horne, E. P. W., Smith, R. E. H. (1990). Ice/water interactions and their effect on biological oceanography in the arctic archipelago. In: Harington, C. R. (ed.) Canada's missing dimension: science and history in the Canadian Arctic islands. Can. Mus. Nat, Ottawa, Vol. 1: 204-228

Cota, G. F. (1985). Photoadaptation of high arctic ice algae Nature, Lond. 315: 219-222

Cota, G. F., Anning, J. L., Harris, L. R., Harrison, W. G., Smith, R. E. H. (1990). The impact of ice algae on inorganic nutrients in seawater and sea ice in Barrow Strait, NWT, Canada during spring. Can. J. Fish. Aquat Sci. 47. $1402-1415$

Cota, G. F., Horne, E. P. W. (1989). Physical control of arctic ice algal production. Mar. Ecol. Prog. Ser 52: 111-121

Cota, G. F., Prinsenberg, S. J., Bennett, E. B., Loder, J. W., Lewis, M. R., Anning, J. L., Watson, N. H. F., Harris, L. R. (1987). Nutrient fluxes during extended blooms of arctic ice algae. J. geophys. Res. 92: 1951-1962

Cota, G. F., Sullivan, C. W. (1990). Photoadaptation, growth and production of bottom ice algae in the Antarctic. J. Phycol. 26: 399-411

Cota, G. F., Sullivan, C. W., Priscu, J. C. (1988). Uptake of inorganic nitrogen by ice algae in McMurdo Sound, Antarctica. EOS Trans. Am. geophys. Un. 69: 1104

Demers, S., Legendre, L., Maestrini, S. Y., Rochet, M, Ingram, R. G. (1989). Nitrogenous nutrition of sea-ice microalgae. Polar Biol. 9: 377-383

Dugdale, R. C. (1967). Nutrient limitation in the sea: dynamics, identification and significance. Limnol. Oceanogr. 12: 685-695

Dugdale, R. C., Goering, J. J. (1967). Uptake of new and regenerated forms of nitrogen in primary productivity. Limnol. Oceanogr. 12: 196-206

Eppley, R. W. (1972). Temperature and phytoplankton growth in the sea. Fish. Bull. U.S. 70: 1063-1085

Eppley, R. W., Coatsworth, J. L., Solorzano, L. (1969a). Studies of nitrate reductase in marine phytoplankton. Limnol. Oceanogr. 14: 194-205

Eppley, R. W., Peterson, B. J. (1979). Particulate organic matter flux and plankton new production in the deep ocean. Nature, Lond. 282: 477-480

Eppley, R. W., Rogers, J. N., McCarthy, J. J. (1969b). Halfsaturation constants for uptake of nitrate and ammonium by marine phytoplankton. Limnol. Oceanogr. 14: 912-920

Fiedler, R., Proksch, G. (1975). The determination of nitrogen15 by emission and mass spectrometry in biochemical analysis: a review. Analytica chim. Acta 78: 1-62

Garrison, D. L., Buck, K. R. (1986). Organism losses during ice melting: a serious bias in sea ice community studies. Polar Biol. 6: 237-239

Glibert, P. M., Lipschultz, F., McCarthy, J. J., Altabet, M. A. (1982). Isotope dilution models of uptake and remineralization of ammonium by marine plankton. Limnol. Oceanogr. 27: 639-650

Goldman, J. C. (1980). Physiological processes, nutrient availability, and the concept of relative growth rate in marine phytoplankton ecology. In: Falkowski, P. G. (ed.) Primary productivity in the sea. Plenum Press, New York, p. $179-194$

Gosselin, M., Legendre, L., Demers, S., Ingram, R. G. (1985). Responses of sea-ice microalgae to climatic and fortnightly tidal energy inputs (Manitounuk Sound, Hudson Bay). Can. J. Fish. Aquat Sci. 42: 999-1006

Gosselin, M., Legendre, L., Michel, C., Demers, S., Therriault, J.-C., Harrison, W. G., Turpin, D. H. (1990b). Seasonal variations in the utilization of nitrogen and inorganic carbon by sea-ice microalgae (Hudson Bay, Canadian Arctic). Mar. Ecol. Prog. Ser. (in press).

Gosselin, M., Legendre, L., Therriault, J.-C., Demers, S. (1990a). Light and nutrient limitation of sea-ice microalgae (Hudson Bay, Canadian Arctic). J. Phycol. 26: 220-232

Gosselin, M., Legendre, L., Therriault, J. C., Demers, S., Rochet, M. (1986). Physical control of the horizontal patchiness of sea-ice microalgae. Mar. Ecol. Prog. Ser 29: 289-298

Grossi, S. M., Kottmeier, S. T., Moe, R. L., Taylor, G. T., Sullivan, C. W. (1987). Sea ice microbial communities. VI. Growth and primary production in bottom ice under graded snow cover Mar. Ecol. Prog. Ser. 35: $153-164$

Grossi, S. M., Kottmeier, S. T., Sullivan, C. W. (1984). Sea ice microbial communities. III. Seasonal abundance of microalgae and associated bacteria, McMurdo Sound, Antarctica. Mucrob. Ecol. 10: 231-242

Harrison, W G. (1980). Nutrient regeneration and primary production in the sea. In: Falkowski, P. G. (ed.) Primary productivity in the sea. Plenum Press, New York, p. $433-460$

Hochman, A., Nissany, A., Wynne, D., Kaplan, B., Berman, T (1986). Nitrate reductase: an improved assay method for phytoplankton. J. Plankton Res. 8: 385-392

Holm-Hansen, O., Lorenzen, C. J., Holmes, R. W., Strickland, J. D. H. (1965). Fluorometric determination of chlorophyll. J. Cons. int. Explor. Mer 30: 3-15

Horner, R. A. (1985a). History of ice algal investigations. In: 
Horner, R. A. (ed.) Sea ice biota. CRC Press, Boca Raton, Fla. p. $1-19$

Horner, R. A. (1985b). Ecology of sea ice microalgae. In Horner, R. A. (ed.) Sea ice biota. CRC Press, Boca Raton Fla, p. 83-103

Horner, R. A., Syvertsen, E. E., Thomas, D. P., Lange, C. (1988). Proposed terminology and reporting units for sea ice algal assemblages. Polar Biol. 8: 249-253

Laws, E. A., Bannister, T T. (1980). Nutrient- and light-limited growth of Thalassiosira fluviatilis in continuous culture, with implications for phytoplankton growth in the ocean. Limnol. Oceanogr. 25: 457-473

Lewis, M. R., Smith, J. C. (1983). A small volume, shortincubation-time method for measurement of photosynthesis as a function of incident irradiance. Mar. Ecol. Prog. Ser. 13: 99-102

Maestrini, S. Y., Rochet, M., Legendre, L., Demers, S. (1986) Nutrient limitation of the bottom-ice microalgal biomass (southeastern Hudson Bay, Canadian Arctic). Limnol. Oceanogr. 31: 969-982

McCarthy, J. J. (1970). A urease method for urea in seawater Limnol. Oceanogr. 15: 309-311

McCarthy, J. J., Taylor, W. R., Taft, J. L. (1977). Nitrogenous nutrition of the plankton in Chesapeake Bay. I. Nutrient availability and phytoplankton preferences. Limnol. Oceanogr. 22: 996-1011

Michel, C., Legendre, L., Demers, S., Therriault, J. C. (1988). Photoadaptation of sea-ice microalgae in springtime: photosynthesis and carboxylating enzymes. Mar. Ecol. Prog. Ser. 50: 177-185

Morel, F. M. M., Rueter, J. G., Anderson, D. M., Guillard, R. R. L. (1979). AQUIL: a chemically defined phytoplankton culture medium for trace metal studies. J. Phycol. 15: 135-141

Nelson, D. M., Gordon, L. I. (1982). Production and pelagic dissolution of biogenic silica in the southern ocean. Geochim, cosmochim. Acta 46: 491-501

Palmisano, A. C., SooHoo, J. B., Sullivan, C. W. (1985). Photosynthesis-irradiance relationships in sea ice microalgae from McMurdo Sound, Antarctica, J. Phycol. 21 $341-346$

Priscu, J. C., Lizotte, M. P., Cota, G. F., Palmisano, A. C., Sullivan, C. W. (1990). Diel patterns of photosynthesis and nitrogen uptake by Antarctic sea ice microalgae: response

This article was presented by $\operatorname{Dr} M . R$. Lewis, Washington, D.C., USA to continuous but variable irradiance. Mar. Ecol. Prog. Ser. (in press)

Priscu, J. C., Palmisano, A. C., Priscu, L. R., Sullivan, C. W. (1989). Temperature dependence of inorganic nitrogen uptake and assimilation in Antarctic sea-ice microalgae. Polar Biol. 9: 443-446

Rivkin, R. B., Putt, M. (1987). Heterotrophy and photoheterotrophy by antarctic microalgae: light-dependent incorporation of amino acids and glucose. J. Phy col. 23: 442-452

Sharp, J. H. (1974). Improved analysis for particulate organic carbon and nitrogen' from seawater Limnol. Oceanogr 19: $984-989$

Smith, R. E. H., Anning, J. L., Clement, P., Cota, G. (1988). Abundance and production of ice algae in Resolute Passage, Canadian Arctic. Mar. Ecol. Prog. Ser. 48: 251-263

Smith, R. E. H., Clement, P., Cota, G. F. (1989a). Population dynamics of bacteria in Arctic sea ice. Microb. Ecol. 17 $63-76$

Smith, R. E. H., Clement, P., Cota, G. F., Li, W. K. W. (1987). Intracellular photosynthate allocation and the control of arctic marine ice algal production. J. Phycol. 23: $124-132$

Smith, R. E. H., Clement, P., Head, E. (1989b). Biosynthesis and photosynthate allocation patterns of Arctic ice algae. Limnol. Oceanogr. 34: 591-605

Smith, R. E. H., Harrison, W. G., Harris, L. R., Herman, A. W. (1990). Vertical fine structure of bottom ice biota in the high Arctic. Can. J. Fish Aquat Sci. 47: 1348-1355

Solorzano, L. (1969). Determination of ammonia in natural waters by the phenoihypochlorite method. Limnol Oceanogr 14: 799-801

Sommer, U. (1986). Nitrate- and silicate-competition among Antarctic phytoplankton. Mar. Biol. 91: 345-351

Strickland, J. D. H., Parsons, T R. (1972). A practical handbook of seawater analysis. Bull. Fish. Res. Bd Can. 167 $1-311$

Welch, H. E., Bergmann, M. A. (1989). Seasonal development of ice algae and its prediction from environmental factors near Resolute, N.W.T., Canada. Can. J. Fish. Aquat. Sci 46: 1793-1804

Wheeler, P. A., Kirchman, D. L. (1986). Utilization of inorganic and organic nitrogen by bacteria in marine systems. Limnol. Oceanogr 31, 998-1009

Manuscript first received: August 16, 1989

Revised version accepted: July 31, 1990 